\title{
KONSEP DASAR GERAKAN LITERASI SEKOLAH \\ PADA PERMENDIKBUD NOMOR 23 TAHUN 2015 \\ TENTANG PENUMBUHAN BUDI PEKERTI
}

\author{
Ika Fadilah Ratna Sari
}

Universitas Islam Negeri Sunan Kalijaga Yogyakarta

Email: fadilahratnasari@gmail.com

\begin{abstract}
ABSTRAK
Gerakan Literasi Sekolah (GLS) memperkuat gerakan penumbuhan budi pekerti sebagaimana dituangkan dalam Peraturan Menteri Pendidikan dan Kebudayaan Nomor 23 Tahun 2015. Salah satu kegiatan di dalam gerakan tersebut adalah kegiatan 15 menit membaca buku nonpelajaran sebelum waktu belajar dimulai. Kegiatan ini dilaksanakan untuk menumbuhkan minat baca peserta didik serta meningkatkan keterampilan membaca agar pengetahuan dapat dikuasai secara lebih baik. Materi baca berisi nilai-nilai budi pekerti, berupa kearifan lokal, nasional, dan global yang disampaikan sesuai tahap perkembangan peserta didik. Penerapan kegiatan ini juga perlu memperhatikan konsep dasar pelaksanaan gerakan literasi sekolah sesuai pada Permendikbud nomor 23 Tahun 2015, sehingga mampu mencapai tujuan yang diharapkan. Tujuan penelitian ini adalah menganalisis konsep dasar literasi sekolah pada Permendikbud Nomor 23 Tahun 2015 tentang Penumbuhan Budi Pekerti. Penelitian ini merupakan penelitian kualitatif deskriptif dengan menggunakan analisis isi. Sumber data yang digunakan berupa dokumen dan informan. Berdasarkan hasil analisis data dapat disimpulkan sebagai berikut: (1) literasi adalah kemampuan untuk menggunakan bahasa dan gambar dalam bentuk yang kaya dan beragam untuk membaca, menulis, mendengarkan, berbicara, melihat, menyajikan dan berpikir kritis tentang ide-ide sehingga mampu menjelaskan praktik sosial dan budaya serta makna yang terkandung dengan berorientasi pada teks
\end{abstract}


cetak maupun multidimensi dan interaktif secara kritis; (2) komponen literasi terdiri atas literasi dini, literasi dasar, literasi perpustakaan, literasi media, literasi teknologi, dan literasi visual; (3) GLS adalah suatu usaha atau kegiatan yang bersifat partisipatif dengan melibatkan warga sekolah, akademisi, penerbit, media massa, masyarakat, dan pemangku kepentingan di bawah koordinasi Direktorat Jenderal Pendidikan Dasar dan Menengah Kementerian Pendidikan dan Kebudayaan dengan upaya pada peserta didik membaca 15 menit sebelum pelajaran dimulai; dan (4) GLS dapat dilihat dari beberapa sudut pandang, antara lain yaitu segi pendidikan, segi komunikasi, segi budaya, segi bahasa, segi kognitif, segi pertumbuhan perngetahuan dan segi agama Islam.

\section{Kata kunci: literasi dan konsep dasar.}

\section{ABSTRACT}

School Literacy Movement (SLM) strengthens the growth movement of character as stated in the Minister of Education and Culture Regulation No. 23 of 2015. One of the activities in the movement is a 15-minute activity of reading non-learning books before the learning time begins. This activity is carried out to foster students' interest in reading and improve reading skills so that knowledge can be mastered better. Reading material contains the values of manners, in the form of local, national and global wisdom which are delivered according to the stages of development of students. The implementation of this activity also needs to pay attention to the basic concept of implementing the school literacy movement in accordance with the Minister of Education and Culture Regulation Number 23 of 2015, so as to be able to achieve the expected goals. The purpose of this study is to analyze the basic concepts of school literacy in the Minister of Education and Culture Regulation No. 23 of 2015 concerning the growth of characteristics. This research is a descriptive qualitative research using content analysis. Source of data used in the form of documents and informants. Based on the results of data analysis can be summarized as follows: (1) literacy is the ability to use language and images in rich and diverse forms to read, write, listen, speak, see, present and think critically about ideas so as to explain social practices and the culture and meaning contained by critically 
oriented print and multidimensional and interactive texts; (2) literacy components consist of early literacy, basic literacy, library literacy, media literacy, technology literacy, and visual literacy; (3) SLM is a participatory business or activity involving school citizens, academics, publishers, mass media, communities, and stakeholders under the coordination of the Directorate General of Primary and Secondary Education of the Ministry of Education and Culture with an effort to read 15 minutes of students before the lesson starts; and (4) SLM can be seen from several perspectives, including the aspects of education, aspects of communication, aspects of culture, aspects of language, aspects of cognitive, aspects of growth of knowledge and aspects of Islam.

\section{Keywords: literacy and basic concepts.}

\section{A. PENDAhuluan}

Secara tradisional literasi dipandang sebagai kemampuan membaca dan menulis. Pada awalnya, seseorang dikatakan literat jika ia mampu membaca dan menulis. Sejalan dengan perubahan waktu, definisi literasi pun bergeser dari pengertian yang sempit sebagai keterampilan berbahasa menuju pengertian yang lebih luas menjadi literasi dalam berbagai ilmu. Oleh sebab itu, kemampuan literasi bidang ilmu menjadi kemampuan penting yang harus dikuasai siswa agar bisa hidup dan berkehidupan pada abad ke-21 ini.

Pada abad ke-21 ini, kemampuan literasi peserta didik berkaitan erat dengan tuntutan keterampilan membaca yang berujung pada kemampuan memahami informasi secara analitis, kritis dan reflektif. Akan tetapi, pembelajaran di sekolah saat ini belum mampu mewujudkan hal tersebut. Berbicara tentang kemampuan literasi siswa di Indonesia, kemampuan literasi siswa Indonesia saat ini masih cukup memprihatinkan. Hal ini disebabkan oleh kenyataan bahwa sejak tahun 2000 kemampuan literasi membaca, literasi sains, dan literasi matematika siswa Indonesia masih rendah jika dibandingkan dengan siswa di negara lain. Dari survei yang dilakukan TIMSS dan PIRLS yang dilakukan tahun 2015, siswa Sekolah Dasar (SD) di Indonesia masih menempati urutan bawah dibanding negara lain. ${ }^{1}$

1. "Data Hasil TIMSS," t.t., https://www.google.com/search?q=puspendik.kemdikbud. go.id\%2F...\%2FHasil\%2520Seminar\%2520 Puspendik\%25\&ie=utf-8\&oe=utf$8 \&$ client=firefox-b. pada tanggal 11 Maret 2018 pukul 11.25. 
Berpijak pada data empiris di atas, upaya meningkatkan literasi siswa hendaknya dilakukan sedini mungkin agar kompetensi literasi para siswa dapat meningkat. Kementerian Pendidikan dan Kebudayaan mengembangkan GLS yang melibatkan semua pemangku kepentingan dibidang pendidikan, mulai dari tingkat pusat, provinsi, kabupaten/ kota, hingga satuan pendidikan. Selain itu melibatkan eksternal dan unsur publik, yakni orang tua peserta didik, alumni, masyarakat, dunia usaha dan industri juga menjadi komponen penting dalam GLS. GLS ini memperkuat gerakan penumbuhan budi pekerti sebagaimana dituangkan dalam Peraturan Menteri Pendidikan dan Kebudayaan Nomor 23 Tahun 2015. Untuk melaksanakan kegiatan GLS, perlu diketahui konsep dasar GLS yang akan diimplementasikan. Maka dari itu, jurnal ini akan membahas mengenai analisis konsep dasar GLS pada Permendikbud nomor 23 Tahun 2015 tentang penumbuhan budi pekerti. Diharapkan pembaca dapat mengetahui analisis konsep dasar GLS pada Permendikbud nomor 23 Tahun 2015 tentang penumbuhan budi pekerti.

\section{B. METODE PENELITIAN}

Penelitian ini merupakan penelitian karya sastra melalui analisis dokumen berupa studi pustaka. Bentuk penelitian ini adalah deskriptif kualitatif yang berupa penggambaran dari suatu keadaan tertentu dengan menggunakan metode interaktif. Metode interaktif digunakan untuk menelaah isi dari suatu dokumen. Sumber data yang digunakan penelitian ini adalah dokumen. Sumber data dokumen yaitu berupa Permendikbud Nomor 23 Tahun 2015 tentang Penumbuhan Budi Pekerti. Sementara itu, sumber informan, yaitu Mahasiswa Magister Program Studi PGMI angkatan 2017 di UIN Sunan Kalijaga Yogyakarta.

Teknik pengumpulan data dalam penelitian ini adalah analisis isi dan wawancara mendalam. Analisis isi yaitu dengan mencatat dokumen atau arsip yang berkaitan erat dengan tujuan penelitian. Analisis isi dilakukan dengan membahas konsep dasar literasi sekolah. Hal ini dilakukan dengan pencatatan makna literasi sekolah secara interpretasi. Sementara itu, wawancara mendalam yaitu dengan informan yang dilakukan untuk mendapat data yang tidak bisa diperoleh melalui analisis isi. Wawancara mendalam dilakukan dengan berdiskusi oleh Mahasiswa Magister Program Studi PGMI angkatan 2017 di UIN Sunan Kalijaga Yogyakarta. Pada penelitian ini juga menggunakan pendekatan hermeneutik. Pendekatan hermeneutik adalah sudut pandang bagaimana cara untuk menafsirkan simbol-simbol yang terwujud dalam teks atau bentuk-bentuk lainnya. Pada pendekatan hermeneutik ini, 
peneliti akan menafsirkan makna dari GLS yang tertera pada Permendikbud Nomor 23 Tahun 2015 tentang Penumbuhan Budi Pekerti.

Prosedur analisis data dengan reduksi data, penyajian data, dan penarikan kesimpulan. Reduksi data dilakukan dengan pengumpulan informasi dan data mengenai konsep dasar literasi sekolah dari pengumpulan dokumen dan diskusi secara mendalam. Kemudian penyajian data dilakukan dengan pemaparan informasi dengan menyederhanakan makna dan menginterpretasikan informasi. Selanjutnya, penarikan kesimpulan dilakukan dengan cara memberikan kesimpulan dari hasil penelitian sesauai dengan tujuan yang diharapkan oleh peneliti.

\section{HASIL PENELITIAN DAN PEMBAHASAN}

Secara tradisional, literasi dipandang sebagai kemampuan membaca dan menulis. Pengertian literasi selanjutnya berkembang menjadi kemampuan membaca, menulis, berbicara dan menyimak. Jika diselisik secara komprehensif, perubahan konsepsi literasi terjadi dalam lima generasi. Pada masa perkembangan awal, literasi didefinisikan sebagai kemampuan untuk menggunakan bahasa dan gambar dalam bentuk yang kaya dan beragam untuk membaca, menulis, mendengarkan, berbicara, melihat, menyajikan dan berpikir kritis tentang ide-ide. Perkembangan kedua, literasi sebagai praktik sosial dan budaya tinimbang dipandang sebagai prestasi kognitif yang bebas konteks.

Dalam generasi ketiga, literasi diperluas ke dalam beberapa jenis elemen literasi, seperti visual, auditori dan spasial daripada kata-kata yang tertulis. Dalam generasi keempat, literasi dipandang sebagai konstruksi sosial dan tidak pernah netral. Teks yang ditulis seorang peneliti telah dibentuk berdasarkan posisi mereka (di mana mereka berada dan di mana mereka berdiri, serta bagaimana posisi ini memungkinkan mereka untuk melihat dan tidak melihat). Generasi kelima, untuk menjadi literat pada abad informasi ini berarti harus mampu untuk terlibat dalam berbagai praktik literasi, serta mampu menggambarkan berbagai perangkat keterampilan literasi dalam keberagaman domain literasi. Istilah literasi generasi kelima ini dikenal dengan istilah multiliterasi. ${ }^{2}$

Konsep multiliterasi menurut Eisner menyatakan bahwa multiliterasi merupakan kemampuan membaca, menulis puisi, membagi, melukis, menari, menulis novel

2. Yunus Abidin, Mulyati Tita, dan Hana Yunansah, Pembelajaran Literasi: Strategi Meningkatkan Kemampuan Literasi Matematika, Sains, Membaca dan Menulis (Jakarta: Bumi Aksara, 2017), hlm. 1-4. 
ataupun kemampuan berkontak dengan berbagai media yang memerlukan literasi. Dengan demikian, Eisner berpendapat bahwa literasi dapat dipandang sebagai cara untuk menemukan dan membuat makna dari berbagai bentuk representasi yang ada di sekitar kita. ${ }^{3}$ Pandangan Eisner di atas, senada dengan pandangan C. Luke yang menyatakan bahwa multiliterasi merupakan kemampuan memandang pengetahuan secara integratif, tematik, multimodal dan interdisipliner. Berdasarkan sudut pandang ini, upaya membangun makna dapat dilakukan terhadap berbagai bentuk media komunikasi. ${ }^{4}$

Literasi lebih dari sekadar membaca dan menulis, namun mencakup keterampilan berpikir menggunakan sumber-sumber pengetahuan dalam bentukcetak, visual, digital, dan auditori. Di abad 21 ini, kemampuan ini disebut sebagai literasi informasi dalam konteks Indonesia, literasi dini diperlukan sebagai dasar pemerolehan berliterasi tahap selanjutnya. Komponen literasi tersebut dijelaskan sebagai berikut:

1. Literasi Dini (Early Literacy), yaitu kemampuan untuk menyimak, memahami bahasa lisan, dan berkomunikasi melalui gambar dan lisan yang dibentuk oleh pengalamannya berinteraksi dengan lingkungan sosialnya di rumah.

2. Literasi Dasar (Basic Literacy), yaitu kemampuan untuk mendengarkan, berbicara, membaca, menulis, dan menghitung (counting) berkaitan dengan kemampuan analisis untuk memperhitungkan (calculating), mempersepsikan informasi (perceiving), mengomunikasikan, serta menggambarkan informasi(drawing) berdasarkan pemahaman dan pengambilan kesimpulan pribadi.

3. Literasi Perpustakaan (Library Literacy), antara lain, memberikan pemahaman cara membedakan bacaan fiksi dan nonfiksi, memanfaatkan koleksi referensi dan periodikal, memahami Dewey Decimal System sebagai klasifikasi pengetahuan yang memudahkan dalam menggunakan perpustakaan, memahami penggunaan katalog dan pengindeksan, hingga memiliki pengetahuan dalam memahami informasi ketika sedang menyelesaikan sebuah tulisan, penelitian, pekerjaan, atau mengatasi masalah.

4. Literasi Media (Media Literacy), yaitu kemampuan untuk mengetahui berbagai bentuk media yang berbeda, seperti media cetak, media elektronik (media radio, media televisi), media digital (media internet), dan memahami tujuan penggunaannya.

3. W. Kist, New Literacies in Action: Teaching and Learning in Multiple Media (New York: Teachers College, Colombia University, 2005), hlm. 12.

4. Ibid., hlm. 41.

94 AL-BIDAYAH, Volume 10, Nomor 01, Juni 2018 
5. Literasi Teknologi (Technology Literacy), yaitu kemampuan memahami kelengkapan yang mengikuti teknologi seperti peranti keras (hardware), peranti lunak (software), serta etika dan etiket dalam memanfaatkan teknologi.

6. Literasi Visual (Visual Literacy), adalah pemahaman tingkat lanjut antara literasi media dan literasi teknologi, yang mengembangkan kemampuan dan kebutuhan belajar dengan memanfaatkan materi visual dan audiovisual secara kritis dan bermartabat. $^{5}$

GLS merupakan merupakan suatu usaha atau kegiatan yang bersifat partisipatif dengan melibatkan warga sekolah (peserta didik, guru, kepala sekolah, tenaga kependidikan, pengawas sekolah, Komite Sekolah, orang tua/ wali murid peserta didik), akademisi, penerbit, media massa, masyarakat (tokoh masyarakat yang dapat merepresentasikan keteladanan, dunia usaha, dll.), dan pemangku kepentingan di bawah koordinasi Direktorat Jenderal Pendidikan Dasar dan Menengah Kementerian Pendidikan dan Kebudayaan. Upaya yang ditempuh untuk mewujudkannya berupa pembiasaan membaca pada peserta didik. Pembiasaan ini dilakukan dengan menggunakan 15 menit sebelum hari pembelajaran untuk membaca buku selain buku mata pelajaran (setiap hari). ${ }^{6}$ Ketika pembiasaan membaca terbentuk, selanjutnya akan diarahkan ke tahap pengembangan, dan pembelajaran.

Variasi kegiatan dapat berupa perpaduan pengembangan keterampilan reseptif maupun produktif. Dalam pelaksanaannya, pada periode tertentu yang terjadwal, dilakukan asesmen agar dampak keberadaan GLS dapat diketahui dan terus-menerus dikembangkan. GLS diharapkan mampu menggerakkan warga sekolah, pemangku kepentingan, dan masyarakat untuk bersama-sama memiliki, melaksanakan, danmenjadikan gerakan ini sebagai bagian penting dalam kehidupan. ${ }^{7}$

\section{Analisis GLS dari Beberapa Sudut Pandang}

GLS yang tertuang pada Permendikbud Nomor 23 Tahun 2015 tentang penumbuhan budi pekerti diharapkan dapat diterapkan disekolah pada semua jenjang. Sasarannya tidak hanya peserta didik yang melaksanakan kegiatan GLS

5. Hamid Muhammad, Desain Induk Gerakan Literasi Sekolah (Jakarta: Direktorat Jenderal Pendidikan Dasar dan Menengah Kementerian Pendidikan dan Kebudayaan, 2016), hlm. $8-10$.

6. "Peraturan Menteri Pendidikan dan Kebudayaan Republik IndonesiaNomor 23 Tahun 2015 tentang Penumbuhan Budi Pekerti," 2015.

7. Hamid Muhammad, Desain Induk Gerakan ..., hlm. 7-8. 
namun diharapkan semua warga sekolah juga dapat melaksanakan kegiatan GLS. Pandangan GLS ini dapat kita lihat dari beberapa sudut pandang, antara lain sebagai berikut:

1. Segi pendidikan

Literasi kaitannya dengan dunia pendidikan, penggunaan berbagai jenis bentuk teks dan media memberikan peluang untuk memahami berbagai jenis makna yang berbeda. Teks yang bersifat multimodal juga mendorong untuk berpengalaman menginterprestasikan informasi, baik dalam tataran konteks global maupun lokal. Konsep literasi pada dunia pendidikan sebenarnya tidak terlepas dari konsep pedagogik seni, multiple ways of knowing, dan multiple intelegensi, yang telah terbukti memberikan nilai dalam meningkatkan efektivitas lingkungan belajar bagi siswa. Literasi merupakan pendekatan belajar yang dikembangkan berdasarkan kesadaran dan pengakuan atas keberagaman dan kompleksitas perspektif budaya siswa serta keberagaman belajar yang dimilikinya. Oleh sebab itu, pendidikan literasi diyakini mampu menjembatani siswa untuk dapat belajar dan berkarya pada abad ke-21 ini.

Konsep literasi sebagai konsep penting pendidikan abad ke-21 dipertegas oleh Morocco et al. yang menyatakan bahwa kompetensi yang harus dimiliki manusia abad ke-21 adalah kompetensi pemahaman yang tinggi, kompetensi berpikir kritis, kompetensi berkolaborasi, dan komunikasi. Dalam pendapat ini, kompetensi-kompetensi ini dilandasi dan difasilitasi oleh keterampilan literasi.

2. Segi komunikasi

Literasi dipandang sebagai alat yang dapat digunakan untuk beroleh dan mengomunikasikan informasi. Literasi dalam kondisi alamiahnya bersifat multimodal. Hal ini dikarenakan literasi terbentang dari layar komputer multimedia hingga supermarket, yang semakin menunjukkan bahwa teks telah disajikan secara beragam dan dinamis baik dalam bentuk suara, visual, spasial maupun gestur.

3. Segi budaya (fokus pada kelompok)

Literasi ditujukan agar mampu membentuk makna dalam kaitannya dengan kelompok sosial tertentu, lintas kelompok sosial, norma dan nilai yang berlaku dalam kelompok sosial tersebut. Pada aspek budaya lintas budaya ini menyebabkan perubahan dan rekonstruksi makna yang diikuti oleh terjadinya pergeseran budaya, yang berkontribusi pada perubahan identitas dan praktik literasi dari tulisan menuju literasi visual. 
4. Segi bahasa (fokus pada teks)

Literasi dilakukan agar mampu menggunakan berbagai sistem bahasa untuk mengkonstruksi makna tertentu. Bahasa sendiri mempunyai variasi bentuk makna dalam hubungannya dengan variasi fungsi makna. Tata bahasa tidak dapat hanya ditafsirkan sebagai aturan bahasa tulis, melainkan lebih luas sebagai aturan penggunaan bahasa dalam lingkup yang sangat luas dengan melibatkan media penyampai makna yang sangat bervariasi.

5. Segi kognitif (berfokus pada berpikir)

Literasi ditujukan agar menggunakan berbagai proses dan strategi mental untuk membentuk makna tertentu berdasarkan teks, tujuan, dan audiens.

6. Segi pertumbuhan pengetahuan (berfokus pada pengetahuan)

Literasi ditujukan agar mampu mengembangkan dimensi literasi yang dimilikinya hingga mampu menegoisasi makna yang terkandung dalam teks. ${ }^{8}$

7. Segi agama Islam

Allah menurunkan surat Al-'Alaq sebelum surat-surat lain, yang memerintahkan hamba-hamba-Nya untuk membaca sebelum memerintahkan yang lain. Hal ini tentu karena mengingat betapa pentingnya membaca. Makna Iqra' bukan sekadar bacalah, tetapi budayakanlah menelaah, menganalisis, mengkaji, dan meneliti.

Sejalan dengan sudut pandang di atas, paradigma pembelajaran literasi berkembang dari waktu ke waktu. Paradigma tertua yaitu paradigma dekoding. Dalam pandangan ini literasi merupakan pembelajaran yang bersifat deduktif. Basis pembelajaran literasi terletak pada aspek grafofonemik, yang selanjutnya bergerak pada aspek morfomik dalam rangka menghasilkan makna. Paradigma kedua dikenal dengan istilah paradigma keterampilan. Dalam pemahaman ini, pemahaman terhadap morfem dianggap sebagai basis bagi perkembangan kemampuan literasi. Pembelajaran bahasa masih dipandang sebagai pembelajaran yang bersifat deduktif, bergerak dari pembelajaran satuan menuju bagian dan pembelajaran literasi masih dipandang sebagai proses individual.

Paradigma ketiga yaitu paradigma whole language. Dalam pandangan paradigma ini, fokus pembelajaran literasi adalah makna. Pembelajaran literasi bergerak dari pemahaman makna menuju analisis sintaksis dan grafomorfemik. Pemahaman

8. Abidin, Tita, dan Yunansah, Pembelajaran Literasi: Strategi..., hlm. 6-18. 
literasi dipandang sebagai proses kesatuan menuju bagian dan pembelajaran literasi dipandang sebagai pembelajaran yang bersifat induktif. Pengembangan kemampuan literasi dilakukan melalui bahasa, belajar bahasa menuju belajar tentang bahasa. Pembelajaran literasi selanjutnya dipandang sebagai proses pembelajaran kolaboratif. ${ }^{9}$

Ketiga paradigma pembelajaran literasi di atas merupakan paradigma pembelajaran literasi yang paling memengaruhi pembelajaran literasi di Indonesia. Paradigma whole language terutama hingga saat ini dipandang sebagai paradigma terbaru dalam pembelajaran literasi.

\section{KESIMPULAN}

Pada pembahasan bab sebelumnya mengenai analisis konsep dasar gerakan literasi sekolah pada Permendikbud Nomor 23 Tahun 2015 dapat disimpulkan sebagai berikut:

1. Literasi adalah kemampuan untuk menggunakan bahasa dan gambar dalam bentuk yang kaya dan beragam untuk membaca, menulis, mendengarkan, berbicara, melihat, menyajikan dan berpikir kritis tentang ide-ide sehingga mampu menjelaskan praktik sosial dan budaya serta makna yang terkandung dengan berorientasi pada teks cetak maupun multidimensi dan interaktif secara kritis.

2. Komponen literasi terdiri atas literasi dini, literasi dasar, literasi perpustakaan, literasi media, literasi teknologi, dan literasi visual.

3. GLS adalah suatu usaha atau kegiatan yang bersifat partisipatif dengan melibatkan warga sekolah, akademisi, penerbit, media massa, masyarakat dan pemangku kepentingan di bawah koordinasi Direktorat Jenderal Pendidikan Dasar dan Menengah Kementerian Pendidikan dan Kebudayaan dengan upaya pada peserta didik membaca 15 menit sebelum pelajaran dimulai.

4. GLS dapat dilihat dari beberapa sudut pandang, antara lain yaitu segi pendidikan, segi komunikasi, segi budaya, segi bahasa, segi kognitif, segi pertumbuhan perngetahuan dan segi agama Islam.

\section{E. DAFTAR PUSTAKA}

Abidin, Yunus, Mulyati Tita, dan Hana Yunansah. Pembelajaran Literasi: Strategi Meningkatkan Kemampuan Literasi Matematika, Sains, Membaca dan Menulis. Jakarta: Bumi Aksara, 2017.

9. Ibid., hlm. 6-18. 
"Data Hasil TIMSS," t.t. https://www.google.com/search?q=puspendik.kemdikbud. go.id $\% 2$ F...\%2FHasil $\% 2520$ Seminar $\% 2520 \mathrm{Puspendik} \% 25 \& \mathrm{ie}=$ utf$8 \&$ oe $=$ utf- $8 \&$ client $=$ firefox-b.

Muhammad, Hamid. Desain Induk Gerakan Literasi Sekolah. Jakarta: Direktorat Jenderal Pendidikan Dasar dan Menengah Kementerian Pendidikan dan Kebudayaan, 2016.

"Peraturan Menteri Pendidikan dan Kebudayaan Republik IndonesiaNomor 23 Tahun 2015 tentang Penumbuhan Budi Pekerti,” 2015.

W. Kist. New Literacies in Action: Teaching and Learning in Multiple Media. New York: Teachers College, Colombia University, 2005. 
